\title{
FEEDING FREQUENCY IN PACAMÃ LARVICULTURE ${ }^{1}$
}

\author{
JOSÉ CLAUDIO EPAMINONDAS DOS SANTOS², MARCELO MATTOS PEDREIRA ${ }^{3}$, RONALD KENNEDY LUZ ${ }^{4 *}$
}

\begin{abstract}
The feeding frequencies on pacamã Lophiosilurus alexandri larviculture were evaluated. In the first phase, 10 days of active feeding, larvae with nine days post hatching $(13.5 \pm 0.7 \mathrm{~mm})$ were stocked at density of 10 larvae $\mathrm{L}^{-1}$ in 5-L tanks each. The experimental treatments were: F2T (feeding $8 \mathrm{~h} 00$ and 17h00); F2M (feeding 8h00 and 12h30); F3 (feeding 8h00, $12 \mathrm{~h} 30$ and 17h00); and F4 (feeding 8h00, 11h00, $14 \mathrm{~h} 00$ and 17h00). During this phase Artemia nauplii were used as food. In the second phase, during 15 days, juveniles were restocked in 20-L tanks at density of 2.2 juveniles $\mathrm{L}^{-1}$, and kept the same feeding frequencies of the first phase. Commercial dry diet containing $40 \%$ crude protein was used as food. No effect of feeding frequency on growth and survival, during both phases, was observed. However, survival decreases from the first to the second phase, showing the importance of the type of food. During the L. alexandri larviculture should be recommended twice a day feeding frequency.
\end{abstract}

Keywords: Artemia. Commercial diet. Lophiosilurus alexandri. Feeding management. Carnivorous fish.

\section{FREQUÊNCIA ALIMENTAR NA LARVICULTURA DE PACAMÃ}

RESUMO - Objetivou-se avaliar diferentes frequências alimentares na larvicultura de pacamã Lophiosilurus alexandri. Na primeira fase, com duração de 10 dias, larvas com nove dias pós-eclosão (13,5 $\pm 0,7 \mathrm{~mm})$ foram estocadas na densidade de 10 larvas $\mathrm{L}^{-1}$ em tanques com $5 \mathrm{~L}$ cada. Os tratamentos experimentais foram: F2T (alimentação as 8h00 e 17h00); F2M (alimentação as 8h00 e 12h30); F3 (alimentação as 8h00, 12h30 e 17h00); e F4 (alimentação as 8h00, 11h00, $14 \mathrm{~h} 00$ e 17h00). Durante esta fase foram utilizados náuplios de Artemia como alimento. Na segunda fase, com duração de 15 dias, os juvenis foram estocados em tanques com $20 \mathrm{~L}$ na densidade de 2,2 juvenis $\mathrm{L}^{-1}$, sendo mantidas as mesmas frequências alimentares da primeira fase. A alimentação consistiu no fornecimento de ração comercial contendo $40 \%$ de proteína bruta. Durante as duas fases, as diferentes frequências alimentares não afetaram o desempenho e sobrevivência. No entanto, a sobrevivência diminui da primeira para a segunda fase, mostrando a importância do tipo de alimento. Durante a larvicultura do pacamã pode ser recomendada a frequência alimentar de duas vezes ao dia.

Palavras-chave: Artemia. Lophiosilurus alexandri. Manejo alimentar. Peixe carnívoro. Ração comercial.

\footnotetext{
*Corresponding author

${ }^{1}$ Received for publication in 03/02/2015; accepted in 03/16/2016.

${ }^{2}$ Centro Integrado de Recursos Pesqueiros e Aquicultura de Três Marias, Três Marias, MG, Brazil; claudi_o@yahoo.com.br.

${ }^{3}$ Aquaculture Laboratory, Universidade Federal dos Vales do Jequitinhonha e Mucuri, Diamantina, MG, Brazil; marcelomattospedreira@gmail.com.

${ }^{4}$ Aquaculture Laboratory, Universidade Federal de Minas Gerais, Belo Horizonte, MG, Brazil; luzrk@yahoo.com.br.
} 


\section{INTRODUCTION}

The "pacamã", Lophiosilurus alexandri, is a fish of the Pseudopimelodidae (Siluriformes) family, native to the São Francisco River (SHIBATA, 2003). This species presents flesh with no intramuscular bones, a nice taste, and a fillet yield higher than $40 \%$. It is a fish with carnivorous feeding habits and multiple spawning (COSTA et al., 2015).

Due to these features, studies related to the reproduction under controlled conditions (COSTA et al., 2015), gametogenesis (BARROS et al., 2007), early larvae development (GUIMARÃES-CRUZ et al., 2009), tolerance of larvae to different water salinities (LUZ; SANTOS, 2008a; SANTOS; LUZ, 2009), as well as larviculture using different prey concentrations (SANTOS; CORREIA, LUZ, 2015), lighting conditions (TENÓRIO et al., 2006), stocking density (LÓPEZ; SAMPAIO, 2000; LUZ; SANTOS, 2008b; CORDEIRO et al., 2016), larviculture feeding (PEDREIRA et al., 2008; SANTOS; LUZ, 2009), substrates in the biological filter (PEDREIRA et al., 2009), water temperature (TAKATA et al., 2014), use of anaesthetic (RIBEIRO et al., 2015), and juvenile feeding conditioning at different water salinities (SALARO et al., 2015) have been undertaken to expand knowledge of the cultivation conditions of this species. Nevertheless, studies on the best feeding frequency to be adopted during larviculture have never been done.According to Luz and Portella (2005), the controlled use of different feeding frequencies, such as with Artemia nauplii, deserves attention as it has been little studied in neotropical fish larviculture. It is also important due to the short lifespan of Artemia in freshwater (JOMORI; LUZ; PORTELLA, 2012). Since the appropriate management can lead to better use of labour, an item that contributes significantly to the cost of juvenile fish production (JOMORI et al., 2005), feeding frequency should be well assessed to optimise the laboratory tasks (LUZ; PORTELLA, 2005) and to improve the growth and survival of the animals (RABE; BROWN, 2000; CARNEIRO; MIKOS, 2005; LUZ; PORTELLA, 2005; CANTON et al, 2007). Furthermore, the ideal feeding frequency may increase the opportunity of consumption, reduce aggressive behaviour, and reduce the variation in population size (WANG, HAYAWARD; NOLTIE, 1998).

The aim of this study was to investigate the influence of different feeding frequencies during pacamã larviculture.

\section{MATERIAL AND METHODS}

The experiment was conducted at the Integrated Centre for Fishing Resources and
Aquaculture of Três Marias-Codevasf, Minas Gerais, Brazil and was divided into two phases.

In the first experimental phase, which lasted 10 days of active feeding, pacamã larvae at nine days post-hatch $(13.5 \pm 0.7 \mathrm{~mm}$ and $22.7 \pm 1.2 \mathrm{mg})$ were stocked at a density of 10 larvae $\mathrm{L}^{-1}$ in 16 fully white circular tanks with a useful volume of $5 \mathrm{~L}$ each. The photoperiod was kept at 10 hours of light. Dissolved oxygen (measured with a Horiba U10 device) remained above $5.0 \mathrm{mg} \mathrm{L}^{-1}$ through the use of additional aeration. The water temperature at 9:00 and 17:00 was $26.2 \pm 0.7$ and $26.5 \pm 0.5^{\circ} \mathrm{C}$, respectively.

The treatments consisted of four feeding frequencies (Table 1) with four replicates per frequency using a completely randomised design. For feeding, Artemia cysts were hatched daily in water with a salinity of $30 \mathrm{~g}$ of salt $\mathrm{L}^{-1}$. Immediately after hatching, the nauplii were separated from the remaining cysts and concentrated in water with a salinity of $10 \mathrm{~g}$ of salt $\mathrm{L}^{-1}$, for quantification and then distribution to the animals. The daily concentration of Artemia nauplii was 1,300 and 1,950 larva ${ }^{-1}$ from the first to the fifth day and from the sixth to the tenth day of active feeding, respectively. For the different treatments, the same amounts of prey, divided according to the feeding frequency, were distributed. The rearing system was static. However, in order to maintain water quality, $50 \%$ of the volume of water from each tank was siphoned daily to remove food remnants and faeces (Table 1), and was replaced immediately with water of the same temperature.

For the second phase, which lasted 15 days, pacamã juveniles with the same treatment (feeding frequency) were grouped and redistributed into 12 fully white rectangular tanks with a useful volume of $20 \mathrm{~L}$, in three replicates per treatment. Each tank received 44 animals $\left(2.2\right.$ juveniles $\left.\mathrm{L}^{-1}\right)$. During this phase, the juveniles received, directly, commercial extruded food at the same feeding frequencies as the first experimental phase. The diet $(1.7 \mathrm{~mm}$ diameter, $40 \%$ crude protein, $10 \%$ moisture, $4 \%$ ether extract, $15 \%$ mineral matter, $6 \%$ crude fibre, $5 \%$ calcium, and $1.5 \%$ phosphorus) was ground and sieved $(0.5$ $\mathrm{mm}$ diameter) to be distributed to the animals at will.

The photoperiod and dissolved oxygen conditions were similar to the first phase. The water temperature at 9:00 and 17:00 was $26.0 \pm 0.6$ and $26.0 \pm 0.7^{\circ} \mathrm{C}$, respectively. As in the first phase, the breeding system was static. However, in order to maintain water quality, the tanks were cleaned before each meal (total daily volume of $50 \%$ of the tank volume) and food remnants and faeces were removed (Table 1). The volume removed at each cleaning was immediately replaced with water at the same temperature as the tank. At the time of each cleaning, dead animals were counted and removed to prevent cannibalism. 
Table 1. Treatments during the first experimental phase, 10-day active feeding of pacamã *.

\begin{tabular}{llllllll}
\hline Treatments & & \multicolumn{7}{c}{ Time of day } \\
& $7: 00$ & $8 \mathrm{~h}: 00$ & $11: 00$ & $12: 30$ & $14: 00$ & $16: 30$ & $17: 00$ \\
\hline F2T & $\mathrm{C}$ & $\mathrm{F}$ & - & - & - & $\mathrm{C}$ & $\mathrm{F}$ \\
F2M & $\mathrm{C}$ & $\mathrm{F}$ & - & $\mathrm{F}$ & - & $\mathrm{C}$ & - \\
F3 & $\mathrm{C}$ & $\mathrm{F}$ & - & $\mathrm{F}$ & - & $\mathrm{C}$ & $\mathrm{F}$ \\
F4 & $\mathrm{C}$ & $\mathrm{F}$ & $\mathrm{F}$ & - & $\mathrm{F}$ & $\mathrm{C}$ & $\mathrm{F}$ \\
\hline
\end{tabular}

C - cleaning.

F - feeding.

* In phase two (exclusive use of commercial food) with same feeding frequencies were used. However, tank cleaning was performed before each feeding at different frequencies.

At the end of each experimental phase, survival rate was determined for comparison between the treatments. To monitor the growth of the animals during the two experimental phases, animals were collected after every five days of active feeding to record the total length, measured with a digital Starrett calliper ( $0.01 \mathrm{~mm}$ accuracy), and wet weight, using precision analytic scales (Mars, AY220 model - $0.0001 \mathrm{~g}$ ).

For each replicate, the specific growth rate (SGR) was calculated using the expression:

$\mathrm{SGR}=100 \times(\ln \mathrm{Wf}-\ln \mathrm{Wi}) / \mathrm{t}$,

Where $\mathrm{Wf}$ is the final weight and $\mathrm{Wi}$ is the initial weight and considering the time interval $\mathrm{t}$ (days) between samplings.

For statistical analysis, data were submitted to a normality test (Cramer-von Mises) and variance homoscedasticity test (Levene). The percentage data underwent arcsine transformation for analysis. However, only the actual data is presented here. Data from both phases were submitted to ANOVA and the means were compared by Tukey's test at $5 \%$ probability.

\section{RESULTS AND DISCUSSION}

During the first experimental phase, it is worth noting the high survival rates (above 89\%) after 10 days of active feeding. Furthermore, the animals exceeded $25 \mathrm{~mm}$ in length, a size commonly used for restocking. In addition, the different feeding frequencies did not affect survival, weight, or height (Table 2). A similar result was found for other carnivorous species, such as Hoplias lacerdae (LUZ; PORTELLA, 2005), which also presents benthic behaviour, similar to L. alexandri. According to the authors, this species can also be fed twice daily for the first 15 days of active feeding with Artemia nauplii in freshwater. For Rhinelepis aspera, another benthic species but with detritivorous habits, a feeding frequency of two and four times a day using Artemia nauplii, provided similar weight and survival but longer length for animals fed twice a day for the first seven days of active feeding when kept in water of different salinities (LUZ, SANTOS, 2010). Thus, despite the short lifespan of Artemia nauplii in freshwater (JOMORI; LUZ; PORTELLA, 2012), this fact does not appear to be a limiting factor for these species that received only two feedings per day. However, for Pleuronectes ferrugineus, a marine species, a feeding frequency of once a day showed lower growth (RABE; BROWN, 2000) whereas for Gobio gobio larvae, a frequency of four times a day provides greater growth (KESTEMONT; AWAÏSS, 1989). Thus, the importance of studies investigating the best feeding frequency to be adopted during fish larviculture is clear, and also, that the results may depend on the species studied.

Table 2. Mean values ( \pm standard deviation) of pacamã survival, weight, and length during the first experimental phase.

\begin{tabular}{|c|c|c|c|c|}
\hline & \multicolumn{4}{|c|}{ Treatments } \\
\hline & F2M & F2T & F3 & F4 \\
\hline Final survival rate $(\%)^{\text {ns }}$ & $90.4 \pm 5.3$ & $93.6 \pm 1.7$ & $90.4 \pm 7.2$ & $89.9 \pm 6.1$ \\
\hline Weight (mg) 5 days ${ }^{\text {ns }}$ & $46.8 \pm 7.3$ & $54.5 \pm 7.1$ & $49.3 \pm 4.6$ & $56.5 \pm 9.8$ \\
\hline Weight (mg) 10 days $^{\mathrm{ns}}$ & $140.8 \pm 8.8$ & $149.5 \pm 3.8$ & $151.4 \pm 29.7$ & $162.5 \pm 12.0$ \\
\hline Total length $(\mathrm{mm}) 5$ days ${ }^{\mathrm{ns}}$ & $17.9 \pm 0.7$ & $18.2 \pm 0.7$ & $18.3 \pm 0.4$ & $19.0 \pm 1.0$ \\
\hline Total length (mm) 10 days ${ }^{\mathrm{ns}}$ & $25.6 \pm 0.5$ & $25.9 \pm 0.7$ & $25.0 \pm 1.2$ & $26.1 \pm 0.7$ \\
\hline
\end{tabular}

${ }^{\mathrm{n} s}$ not significant by ANOVA test.

F2M (feeding at 8:00 and 12:30), F2T (feeding at 8:00 and 17:00), F3 (feeding at 8:00, 12:30, and 17:00), and F4 (feeding at 8:00, 11:00, 14:00, and 17:00).

During the second experimental phase, when live food was replaced by commercial food, no effects for the different feeding frequencies with regard to survival, length, and weight were observed (Table 3). These results are similar to those found during the first experimental phase, where a feeding rate of twice a day, regardless of times, can be used for this species. In a study conducted by Souza et al. (2014) with the same species, where food conditioning started with a semi-moist diet (ox heart + 
commercial food mixture until the exclusive supply of commercial food), the feeding frequencies of 3 and 4 times per day also showed no differences in survival (from 57 to $67 \%$ ) and performance of pacamã juveniles.

However, as discussed in the first phase of the experiment, the best feeding frequency for juveniles fed with commercial diets varies from species to species. The performance of Rhamdia quelen juveniles with an average weight of $1.88 \mathrm{~g}$ fed at a frequency of one to four times a day was not affected (CARNEIRO; MIKOS, 2005) while for juveniles of Rhamdia quelen weighing $7.47 \mathrm{~g}$, the weight gain and specific growth rate increased with an increase in feeding frequency, and the authors recommended at least 2 daily feeds (CANTON et al., 2007). For Takifugu rubripes, the recommended feeding frequency also varies according to the size of the animals (KIKUCHI et al., 2006). For Plecoglossus altivellis, a frequency of four times a day provides greatest growth (CHO et al., 2003), and three times a day was considered ideal for breeding a hybrid "sunfish" (WANG, HAYAWARD ; NOLTIE, 1998). These results reinforce the importance of feeding frequency management and should be assessed during the different rearing stages.

Table 3. Mean values ( \pm standard deviation) of survival, mortality, weight, and total length of pacamã after the replacement of live food by a dry diet (from 11 to 25 days of active feeding - second experimental phase)

\begin{tabular}{|c|c|c|c|c|}
\hline & \multicolumn{4}{|c|}{ Treatments } \\
\hline & F2M & $\mathrm{F} 2 \mathrm{~T}$ & F3 & F4 \\
\hline Survival (\%) ${ }^{\mathrm{ns}}$ & $47.7 \pm 15.6$ & $49.5 \pm 12.7$ & $46.8 \pm 12.1$ & $62.1 \pm 2.7$ \\
\hline Weight (mg) 15 days ${ }^{\mathrm{ns}}$ & $161.5 \pm 19.3$ & $173.8 \pm 28.1$ & $179.5 \pm 8.4$ & $213.3 \pm 5.3$ \\
\hline Weight (mg) 20 days $^{\mathrm{ns}}$ & $181.1 \pm 12.1$ & $188.0 \pm 37.7$ & $215.8 \pm 19.8$ & $229.1 \pm 34.5$ \\
\hline Weight (mg) 25 days ${ }^{\mathrm{ns}}$ & $213.6 \pm 40.7$ & $239.1 \pm 29.6$ & $232.9 \pm 10.6$ & $276.9 \pm 2.5$ \\
\hline Total length $(\mathrm{mm}) 15$ days ${ }^{\mathrm{ns}}$ & $25.0 \pm 1.2$ & $25.4 \pm 0.6$ & $26.1 \pm 0.3$ & $26.3 \pm 0.4$ \\
\hline Total length (mm) 20 days ${ }^{\mathrm{ns}}$ & $27.9 \pm 1.2$ & $27.9 \pm 0.6$ & $28.0 \pm 0.4$ & $28.9 \pm 1.5$ \\
\hline Total length $(\mathrm{mm}) 25$ days ${ }^{\mathrm{ns}}$ & $28.5 \pm 0.8$ & $29.0 \pm 1.0$ & $28.6 \pm 0.4$ & $29.0 \pm 0.3$ \\
\hline
\end{tabular}

${ }^{\mathrm{ns}}$ not significant by ANOVA test.

F2M (feeding at 8:00 and 12:30), F2T (feeding at 8:00 and 17:00); F3 (feeding at 8:00, 12:30 and 17:00), and F4 (feeding at $8: 00,11: 00,14: 00$, and 17:00).

Despite the fact that survival was not affected, it is evident survival was lower at the end of the second phase, compared to the end of the first phase, indicating the importance of the type of food supplied during larviculture. A similar result was observed for $H$. lacerdae (LUZ et al., 2002) during a study in which the authors removed the animals from the nurseries where they had natural food and moved them to the laboratory where commercial food was offered. After 16 days, a $27.5 \%$ survival rate was achieved, well below the one in this study. The death of animals, according to the authors, was attributed to rejection of the diet. However, this same study, using the technique of feed conditioning by replacing food ingredients (ox heart + commercial food), resulted in a $96.6 \%$ survival rate. Therefore, alternative forms of feeding, including inert food, should be evaluated during $L$. alexandri larviculture.

Figure 1 shows the start of mortality two days after commencing the distribution of inert food, and there is a tendency of mortality stabilization from the twenty-first day of active feeding (11 days of exclusive feeding with commercial food). Some of the dead animals had no tail, indicating cannibalism, which is common during the phase when food is changed (IMOROU TOKO; FIOGBÉ; KESTEMONT, 2008; LUZ; PORTELLA, 2015).

The SGR was not influenced by the different treatments during the two experimental phases (Figure 2). During the larviculture of $H$. lacerdae (LUZ; PORTELLA, 2005) and R. aspera (LUZ; SANTOS, 2010), different feeding frequencies presented no differences in SGR when Artemia was distributed. However, when the exclusive supply of commercial formulated diet was started (between the 11 th and the 15th days of active feeding), a drastic reduction in SGR occurred, only showing recovery after 20 days of active feeding (10 days after the change of food). This SGR recovery shows the acceptance of the commercial diet. The decrease in SGR with the substitution of live food for inert food, using feed conditioning, as well as a recovery after a few days of receiving an inert diet were also recorded for $H$. lacerdae (LUZ; PORTELLA, 2015), which may be attributed to a period of adaptation to the new diet (DURAY; BAGARINAO, 1984). 


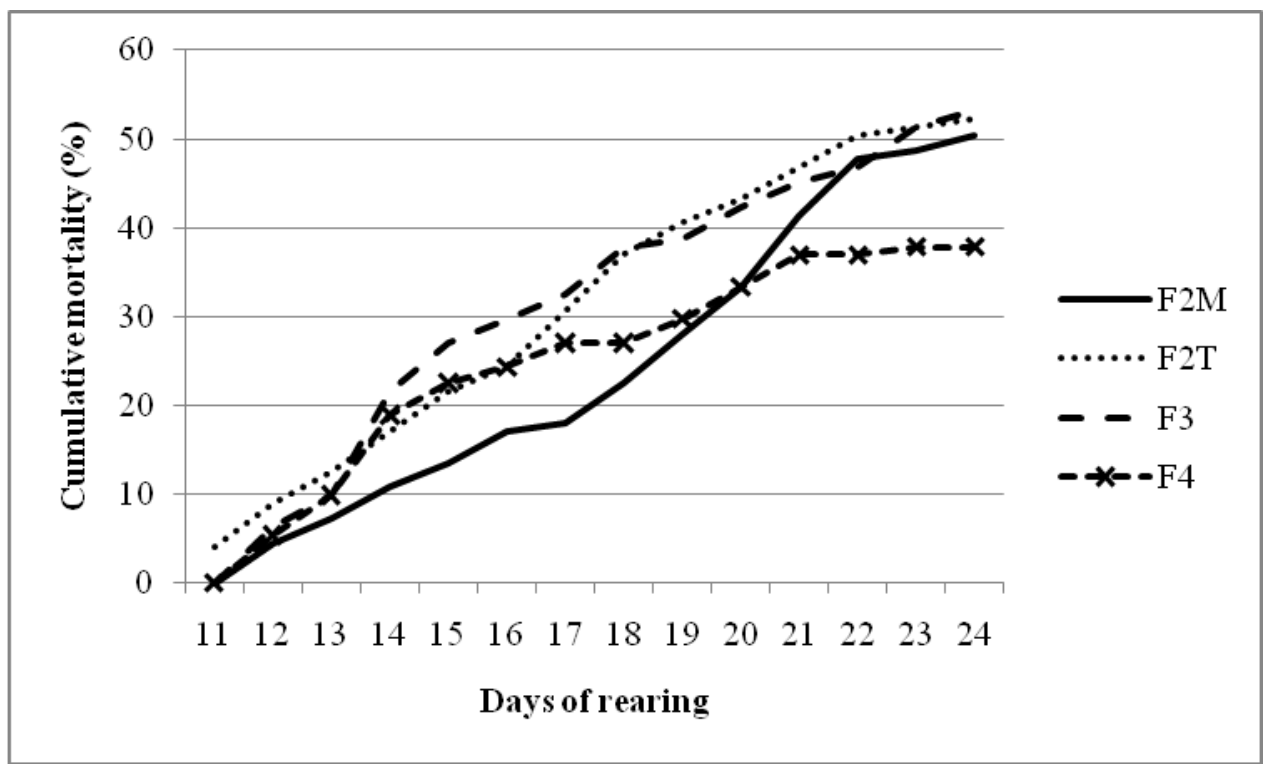

Figure 1. Cumulative mortality of pacamã juveniles during the second experimental phase (11 to 25 days of active feeding) under different feeding frequencies.

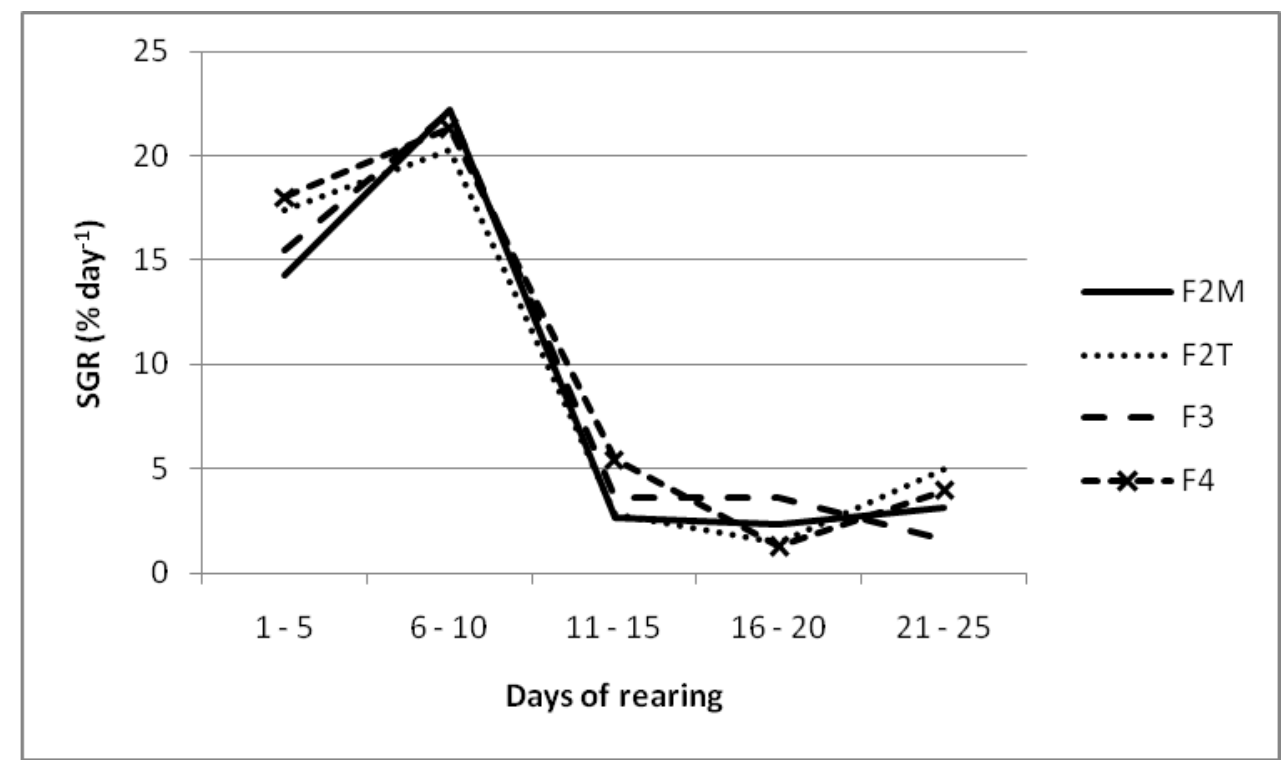

Figure 2. The specific growth rate (SGR) of pacamã subject to different feeding frequencies during the first experimental phase with the use of Artemia nauplii (first 10 days of active feeding) and the second experimental phase using commercial formulated diet (from 11 to 25 days of active feeding).

\section{CONCLUSIONS}

Lophiosilurus alexandri larvae can be reared using a feeding frequency of twice a day when either live food or a commercial formulated diet is used. However, alternative practices during the transition from live food to formulated food should be studied for this species, to seek higher survival rates during this phase.

\section{ACKNOWLEDGEMENTS}

We would like to thank FAPEMIG for the financial support, $\mathrm{CNPq}$ for the research productivity grant to LUZ, R.K., Codevasf / CEMIG partnership, and Dr. Yoshimi Sato for the support for this work.

\section{REFERENCES}

BARROS, M. D. M. et al. Reproductive apparatus and gametogenesis of Lophiosilurus alexandri Steindachner (Pisces, Teleostei, Siluriformes). Revista Brasileira de Zoologia, Curitiba,v. 24, n. 1, p. 213-221, 2007.

CANTON, R. et al. Influência da frequência alimentar no desempenho de juvenis de jundiá. Revista Brasileira de Zootecnia, Viçosa, v. 36, n. 4, 
p. 749-753, 2007.

CARNEIRO, P. C. F.; MIKOS, J. D. Frequência alimentar e crescimento de alevinos de jundiá, Rhamdia quelen. Ciência Rural, Santa Maria, v. 35, n. 1, p. 187-191, 2005.

CHO, S. W. et al. Effects of feeding rate and feeding frequency on survival, growth, and body composition of Ayu post-larvae Plecoglossus altivelis. Journal of the World Aquaculture Society, Baton Rouge, v. 34, n. 1, p. 85-91, 2003.

CORDEIRO, N. I. S. et al. High stocking density during larviculture and effect of size and diet on production of juvenile Lophiosilurus alexandri Steindachner, $1876 \quad$ (Siluriformes: Pseudopimelodidae). Journal of Applied Ichthyology, Hamburg Berlin, v. 32, n. 1, p. 61-66, 2016.

COSTA, D. C. et al. Capture, adaptation and artificial control of reproduction of Lophiosilurus alexandri: A carnivorous freshwater species. Animal Reproduction Science, Werribee, v. 159, s/n, p. 148 $-154,2015$.

DURAY, M. N.; BAGARINAO, T. Weaning of hatchery-bred milkfish larvae from live food to artificial diets. Aquaculture, Amsterdam, v. 41, n. 4, p. 325-332, 1984.

GUIMARÃES-CRUZ, R. J. et al. Early development stages of the catfish Lophiosilurus alexandri Steindachner, 1877 (Pisces: Pseudopimelodidae) from the São Francisco River basin, Brazil. Journal of Applied Ichthyology, Hamburg Berlin, v. 25, n. 3, p. 321-327, 2009.

IMOROU TOKO, I.; FIOGBÉ, E. D.; KESTEMONT, P. Determination of appropriate age and stocking density of vundu larvae, Heterobranchus longifilis (Valenciennes1840), at the weaning time. Aquaculture Research, Danvers, v. 39, n. 1, p. 24-32, 2008.

JOMORI, R. K.: LUZ, R. K.; PORTELLA, M. C. Effect of salinity in larval rearing of pacu, Piaractus mesopotamicus, a freshwater species. Journal of the World Aquaculture Society, Baton Rouge, v. 43, n. 3, p. 423-432, 2012.

JOMORI, R. K. et al. Economic evaluation of Piaractus mesopotamicus juvenile production in different rearing systems. Aquaculture, Amsterdam, v. 234, n. 1-4, p. 175-183, 2005.

KESTEMONT, P.; AWAÏSS, A. Larval rearing of the gudgeon, Gobio gobio L., under optimal conditions of feeding with the rotifer, Brachionus plicatilis O. F. Müller. Aquaculture, Amsterdam, v. 83 , n. 3-4, p. 305-318, 1989

KIKUCHI, K. et al. Effect of feeding frequency, water temperature, and stocking density on the growth of Tiger puffer Takifugu rubripes. Journal of the World Aquaculture Society, Baton Rouge, v. 37 , n. 1, p. 12-20, 2006

LÓPEZ, C. M.; SAMPAIO, E. V. Sobrevivência e crescimento larval do pacamã Lophiosilurus alexandri Steindachner, 1876 (Siluriformes, Pimelodidade), em função de três densidades de estocagem em laboratório. Acta Scientiarum, Maringá, v. 22, n. 2, p. 491-494, 2000.

LUZ, R. K.; PORTELLA, M. C. Effect of prey concentrations and feed training on production of Hoplias lacerdae juvenile. Annals of the Brazilian Academy of Sciences, Rio de Janeiro, v. 87, n. 2, p. 1125-1132, 2015.

LUZ, R. K.; PORTELLA, M. C. Freqüência alimentar na larvicultura de trairão (Hoplias lacerdae). Revista Brasileira de Zootecnia, Viçosa, v. 34, n. 5, p. 1442-1448, 2005.

LUZ, R. K. et al. Condicionamento alimentar de alevinos de trairão (Hoplias cf. lacerdae). Revista Brasileira de Zootecnia, Viçosa, v. 31, n. 5, p. 1881 $-1885,2002$.

LUZ, R. K.; SANTOS, J. C. E. Avaliação da tolerância de larvas do pacamã Lophiosilurus alexandri Steindachner, 1877 (Pisces: Siluriformes) a diferentes salinidades. Acta Scientiarum, Maringá, v. 30, n. 4, p. 345-350, 2008a.

LUZ, R. K.; SANTOS, J. C. E. Densidade de estocagem e salinidade da água na larvicultura do pacamã. Pesquisa Agropecuária Brasileira, Brasília, v. 43, n. 7, p. 903-909, 2008 b.

LUZ, R. K.; SANTOS, J. C. E. Effect of salt addition and feeding frequency on cascudo preto Rhinelepis aspera (Pisces: Loricariidae) larviculture. Journal of Applied Ichthyology, Hamburg Berlin, v. 26, n. 3, p. $453-455,2010$.

PEDREIRA, M. M. et al. Biofiltração da água e tipos de substratos na larvicultura de pacamã. Pesquisa Agropecuária Brasileira, Brasília, v. 44, n. 5, p. 511-518, 2009.

PEDREIRA, M. M. et al. Efeito do tamanho da presa e do acréscimo de ração na larvicultura de pacamã. Revista Brasileira de Zootecnia, Viçosa, v. 37, n. 7, p. 1144-1150, 2008.

RABE, J.; BROWN. J. A. A pulse feeding strategy for rearing larval fish: an experiment with yellowtail 
flounder. Aquaculture, Amsterdam, v. 191, n. 4, p. 289-302, 2000.

RIBEIRO, P. A. P.; RIBEIRO, P. A P. et al. Tricaine as an anaesthetic for larvae and juveniles of Lophiosilurus alexandri, a carnivorous freshwater fish. Aquaculture Research, v. 46, n. 7, p. 17881792, 2015.

SALARO, A. L. et al., Gelatin in replacement of bovine heart in feed training of Lophiosilurus alexandri in different water salinities. Annals of the Brazilian Academy of Sciences, Rio de Janeiro, v. 87, n. 4, p. 2281-2287, 2015.

SANTOS, J. C. E.; LUZ, R. K. Effect of salinity and prey concentrations on Pseudoplatystoma corruscans, Prochilodus costatus and Lophiosilurus alexandri larviculture. Aquaculture, Amsterdam, v. 287, n. 3-4, p. 324-328, 2009.

SANTOS, J. C. E. et al. Effect of daily artemia nauplii concentrations during juvenile production of Lophiosilurus alexandri. Boletim do Instituto de Pesca, São Paulo, v. 41, n. especial, p. 771-776, 2015.

SOUZA, W. S. et al. Frequência alimentar e taxa de arraçoamento durante o condicionamento alimentar de juvenis de pacamã. Pesquisa Agropecuária Brasileira, Brasília, v. 49, n. 8, p. 648-651, 2014.

SHIBATA, O. A. Family Pseudopimelodidae. In: REIS, R. E.; KULLANDER, S. O.; FERRARIS JR, C. J. (Eds) Check list of the freshwater fishes of south and central america. Porto Alegre: EDIPUCRS, 2003. v. 1, p. 401-405.

TAKATA, R. et al. Effect of water temperature and prey concentrations on initial development of Lophiosilurus alexandri Steindachner, 1876 (Siluriformes: Pseudoplimelodidae), a freshwater fish. Neotropical Ichthyology, Porto Alegre, v. 12, n. 4, p. 853-859, 2014.

TENÓRIO, R. A. et al. Crescimento do niquim (Lophiosilurus alexandri Steindachner 1876), em diferentes condições de luminosidade e tipos de alimentos. Acta Scientiarum, Maringá, v. 28, n. 4, p. 305-309, 2006.

WANG, N.; HAYAWARD, R. S.; NOLTIE, D. B. Effect of feeding frequency on food consumption, growth, size variation, and feeding pattern of age- 0 hybrid sunfish. Aquaculture, Amsterdam, v. 165, n. 3-4, p. 261-267, 1998. 